\title{
Die kerugmatiese struktuur as bolwerk teen moralisme in die prediking
}

\author{
T F J Dreyer \\ Universiteit van Pretoria
}

\begin{abstract}
The kerygmatic structure as method in eliminating moralism in preaching

Moralism, although an old fallacy, is still alive in modern preaching. In itself, moralism has an ill-fated effect on the evangelical character of preaching. This paper is an attempt to identify the main source of moralism in modern preaching. From the results it appears that moralism manifests itself once the evangelical imperative is preached in a legalistic manner, without the theological indicative fundamental to every imperative in the Bible. In order to overcome this problem, a homiletical modus operandi has to be identified. The hypothesis of this study is that the evangelical kerygma has an inherent structure consisting of the indicatives and promises of God, which leads the believer to try to achieve the imperative. Once this procedure is followed in preparing a sermon, the danger of moralism is eliminated.
\end{abstract}

\section{INLEIDING}

Die geskiedenis van die prediking reflekteer allerlei '-ismes' wat deur die eeue heen die evangeliese karakter van die prediking bedreig het. Elke '-isme' in die prediking verteenwoordig 'n skeeftrekking en verabsolutering van één bepaalde faset van die kérugma. Welke faset dit ook al mag wees, dit lei in elke geval tot 'n verskraling 
en/of verkragting van die boodskap van die evangelie. Of dit nou die intellektualisme, met sy oorbeklemtoning van die kognitiewe is; die piëtisme met sy oordrewe aksent op die gevoel en ervaring; die metodisme met sy eensydige klem op die metode; die wettisisme met sy verabsolutering van die wet; die moralisme met sy fokus op die moraal - dit tas die hart van die evangelie en die wese van die prediking aan! Ironies genoeg leer predikers nie genoegsaam uit die lesse van die geskiedenis nie. Genoemde en talle ander '-ismes' maak weer, in moderne gedaante, hulle verskyning in die prediking van vandag.

Binne die Nederduitsch Hervornide Kerk het die Proponentseksamenkommissie van 1991 gewaarsku teen die gevaar van moralisme wat in die prediking van studente insluip. Die geldigheid van die aantyging word nie hier ondersoek nie. Genoemde aantyging, in watter mate dit ook al geldigheid mag besit, moet ernstig geneem word, vandaar die aanloop tot hierdie ondersoek.

Om te bepaal wat werklik met moralisme bedoel word, sal moontlike hedendaagse interpretasies van die begrip vasgestel moet word. Nadat die werklike gevaar van moralisme in die prediking onder woorde gebring is, sal daar gepoog moet word om 'n homiletiese werkwyse te poneer wat hierdie gevaar kan omseil of bolwerk. Die hipotese van hierdie studie is dat die inherente struktuur van die Bybelse kerugma die prediking teen moralisme, asook talle ander '-ismes' kan beskerm.

\section{DIE BEGRIP 'MORALISME'}

Trilhaas (1960:1128) definieer in sy artikel in die Religion in Geschichte und Gegenwart moralisme soos volg: 'Der Moralismus ist eine Entartung der Ethik... Moralismus bedeutet dass in seinem Bereich etische Masstäbe, Gesichtspunkte und Werte gar nicht mehr anders als nur in Gesetzlicher Form wahrgenommen werden können'.

Homiletiese navorsing verwys dikwels na die negatiewe uitwerking van moralisme in die prediking. Van Rensburg \& Kellerman (1992:216) dui die volgende moontlike nadelige gevolge van moralisme aan:

* dit perk die werking van die Heilige Gees in;

- dit reduseer en verduister en tas die hart van die evangelie aan;

* dit maak wat bysaak is, tot die hoofsaak.

Floor (1974:19) is van mening dat moralisme na vore tree wanneer die gebooie van die Bybel as geisoleerde wette aan die gemeente voorgehou word. Dan ontaard die prediking in 'n moralistiese sedeles of in 'n aktivistiese program van lewens- en wêreldverbetering. Hy merk ook spore van die moralisme in die sogenaamde politieke teologie '...wat mense doen word tot heil vir die medemens. Heil, verlossing 
word van heiligmaking, van wetsvervulling afhanklik gemaak' (Floor 1974:20). Greidanus (1988:104) wys daarop dat moralisme in die prediking insluip wanneer dit mank gaan aan teologiese diepgang. Daarom is dit noodsaaklik dat teologiese interpretasie 'n onmisbare deel van Bybelse interpretasie moet vorm: '...literary and historical interpretation are incomplete as long as they have missed the text's theocentric focus' (Greidanus 1988:104; vgl ook 117, 119). Met teologiese interpretasie bedoel hy dat ' $n$ bepaalde Bybelgedeelte nie slegs binne sy mikro-konteks verstaan moet word nie, maar dat dit ook teologies, vanuit die makro-konteks van die hele kanon, geinterpreteer moet word. Greidanus (1988:163-167), is ook van mening dat die gevaar van moralisme manifesteer wanneer die histories-kulturele gaping tussen die teks en vandag, geïgnoreer word en etiese uitsprake van die teks direk as eise vir vandag gestel word. Dit gebeur volgens hom veral wanneer die prediker, los van die bedoeling of intensie van die perikoop, afsonderlike elemente van die teks na vandag oordra. Moralisering kan vermy word as die prediker die afsonderlike elemente van die perikoop, in hulle onderlinge samehang, en as boustene vir die ontsluiting van die intensie van die teks, in sy prediking gebruik.

'n Oorreaksie teen die gevaar van moralisme kan die indruk wek dat elke oproep tot bekering, alle waarskuwings teen sonde, elke vermaning oor 'n vergryp teen die wet van God per se moralisties is. Sodanige denke verteenwoordig op sy beurt ook weer 'n skeeftrekking, omdat die Christelike etiek 'n wesenlike deel van die verkondiging is. Die onlosmaklike verband tussen wet en evangelie (De Reuver 1986:50-62); die eis tot aktuele prediking (Jonker $s$ a:106); die aktualiteit van etiese vraagstukke (Cox 1985:101-102); die noodsaaklikheid om in die prediking konkreet te wees (Dreyer 1989:350-369), maak dit onafwendbaar dat prediking ook 'n etiese appèl moet hê.

Indien die Christelike etiek inherent aan die prediking is, word dit 'n kritiese vraag waar die grens tussen etiek en moralisme in die prediking getrek moet word. Van Rensburg \& Kellerman (1992:217) trek 'n bepaalde profiel waaraan die verabsolutering van moralisme herken kan word.

* Die sedelike word losgemaak van die evangelie en eersgenoemde word beklemtoon ten koste van laasgenoemde. Die gebooie in die Bybel word as geïsoleerde wette aan die gemeente voorgehou en ontaard in 'n moralistiese sedeles of in 'n aktivistiese program van lewens- en wêreldverbetering (Floor 1974:19).

- Die oproep tot bekering word losgemaak van die persoon en heilswerk van Jesus Christus. Die gebooie van God word 'n grootheid op sigself los van die lewende verhouding in die geloof met God.

* Wanneer die prediker die heilshistoriese konteks en skopus buite rekening laat, is die gevaar van moralisering wesenlik. 'Men plaatst een is-gelijk-teken tussen 
toen en nu en tracht langs die lijn van vermaning de gemeente van nu te bereiken' (Trimp 1984:191). Gebeure en persone word bloot as aanknopingspunt gebruik om teen sekere euwels te waarsku, of op 'n eksemplariese wyse tot optrede aan te moedig. 'The easiest mistake to make in identifying one's self with the text is to see it as a model for morality rather than a mirror for identity' (Greidanus 1988:175).

- In 'n moralistiese benadering word die skuldgevoel ten koste van die vreugde, wat veronderstel is om met die goeie tyding gepaard te gaan, oorbeklemtoon. Die moraliserende prediker neem sy gemeente saam met hom op 'n 'guilt trip' (Fitzgerald 1980:74). Hierdie benadering oorskadu mettergaan die evangeliese werklikheid om te glo dat vergewing van sonde 'n moontlikheid is.

- Die preektrant van die prediker kan volgens Pieterse ook aanleiding gee tot moralisme. Hy gebruik die term 'kommunikasiegeraas' (Pieterse 1987:90). Die prediker se wyse van oordrag, soos sy stemtoon en gebare, kan 'n boodskap wat inhoudelik nie moralisties van aard is nie, omvorm tot prediking wat as moralisme ervaar en beleef word.

Vanuit hierdie kort oorsig oor moontlike slaggate wat tot moralisme aanleiding kan gee, kan die mees kenmerkende tendense soos volg saamgevat word:

- Etiese aspekte van die boodskap word losgemaak van die grondliggende heilshandelinge van God, wat die basis van die Christelike etiek vorm. Hierdie faset sal in die verdere verloop van die studie nader belig word.

- Etiese uitsprake word, met verbygaan van die kultuur-historiese gaping, net so op die situasie van vandag toegepas. Hierdie probleem is primêr eksegeties van aard en sal nie verder beredeneer word nie. Vir die doel van hierdie ondersoek word volstaan met die onderstreping van die belangrikheid van die verdiskontering van histories-kulturele gegewens vir die korrekte verstaan van die teks.

- Afsonderlike elemente van die teks word, los van die inherente samehang binne die geheeelboodskap van die teks, in isolasie na vandag oorgedra. Dit onderstreep juis die belangrikheid van die onderlinge samehang van die kerugmatiese struktuur wat in die ondersoek verder ontleed sal word.

- Die preekstyl en -trant wat op die affektiewe konsentreer om skuldgevoelens te projekteer, skep by die hoorder die persepsie van moralisme. Die handhawing van die kerugmatiese struktuur in die prediking kan juis, soos later aangetoon sal word, die prediker van hierdie eensydige benadering bevry. 
* Die gebrek aan teologiese diepgang en interpretasie van die boodskap binne die teologiese raamwerk van die hele Skrif, kan ook aanleiding gee tot moralisme. Die hantering van die kerugmatiese struktuur binne die teologiese spanningsveld van die Skrifboodskap, sal ook in die ondersoek uitgewys word.

\section{INDIKATTEF EN IMPERATIEF}

Aan die hand van bogenoemde profiel kan moralisme in die prediking geredelik geïdentifiseer word. Die kritiese vraag bly egter hoe die homileet hom in die voorbereding van sy prediking teen die oorskreiding van hierdie grens kan vrywaar? In die literatuur wat hieroor handel, word daar telkens die gevolgtrekking gemaak dat moralisme insluip wanneer die binding en interafhanklikheid tussen die indikatief en die imperatief van die heil losgelaat word. 'Die hele probleem...trek saam in die verhouding van die indikatief tot die imperatief' (Floor 1974:20; Van Rensburg \& Kellerman 1992:212; Fuchs 1992:115; Pieterse 1988:11). Hierdie samehang tussen imperatief en indikatief word op verskillende maniere beskryf. Elke gawe veronderstel 'n opgawe (Come 1963:235-237). Die indikatief van Jesus se genoegdoening hou ook die imperatief van gelowige reaksie in (Wiederkehr 1982:163). Die imperatiewe in die Bybel is altyd gekoppel aan 'n indikatief (Floor 1974:20).

Pogings word aangewend om ' $n$ basiese grondmotief te poneer wat vir die prediking in alle gevalle as indikatief moet geld. Volgens Floor is die verbond of die koninkryk die groot indikatief wat God daargestel het. Talle ander Bybelse grondmotiewe word ook as indikatiewe aangedui: die genade van God (Kotze 1963:36); 'the indicative of the relationship granted by God' (Fuchs 1992:115); die missionère roeping om 'n lig vir die nasies te wees (Van Rensburg \& Kellerman 1992:220); die eskatologiese perspektief op die komende oordeel van God (Velema 1976:90). Dit sou egter gevaarlik wees om slegs een Bybelse grondmotief as indikatief vir die prediking uit te sonder. Dit sou beteken dat die gekose grondmotief by voorbaat as voorverstaan van die teks geld. Alhoewel die vaste ritme van indikatief en imperatief 'n basiese gegewene dwarsdeur die Skrif is, bied elke perikoop of Bybelse korpus sy eie grondmotief wat as indikatief geld, aan (vgl Floor 1974:21-29; Bornkamm 1961:188).

Die indikatief dui in die struktuur van die kerugma op die heilsdade van God wat as deel van sy genade vir die mens geproklameer word. 'Die imperatief van die Skrif spruit voort vanuit die indikatief van die heil - die heil dan as 'n nuwe bestaanstoestand of ontiese werklikheid' (Louw 1993:42-43). Die kleurrykheid en verskeidenheid van die heilsdade van God in die Ou Testament, asook die heil soos dit in die Nuwe Testament op talle wyses vergestalt word in Jesus Christus, vorm as indikatief, die basis vir die imperatief. Die imperatief is duidelik 'n vrug van die 
indikatief in die lewe van die gelowige. Dit beteken nie dat die indikatief dui op wat God doen en die imperatief op wat die mens doen nie. Dit sou die mens lei tot sinergisme. 'Indikatief en imperatief is hier veeleer die twee kante van dieselfde saak' (Floor 1974:25). Waar die heil van God vir mense as vasstaande sekerheid in die indikatief geproklameer word, en in die geloof bely word, voig die imperatief as onlosmaaklike resultaat van hierdie nuwe ontiese werklikheid. Daartoe word die mens in die prediking telkens deur die imperatief opgeroep. Wanneer die imperatief so in die indikatief begrond word, is dit nie moralisme nie, maar deel van die nuwe lewe waarin die mens hom deur die geloof bevind.

Hierdie verbinding tussen indikatief en imperatief as teenvoeter vir moralisme in die prediking, word, soos aangetoon in die voorafgaande, redelik algemeen aanvaar. In 'n sekere sin sou 'n mens kon beweer dat dit die basiese inherente struktuur van die Bybelse kerugma is dat dit bestaan uit die verweefdheid van indikatief en imperatief. Tog gaan hierdie struktuur mank aan die element van die eskatologiese wat ook 'n onlosmaaklike deel van die kerugma is. Dit was veral Louw (1993:38-50) wat in sy pastorale model poog om ook die eskatologiese element van die kerugma te integreer. In die lig van sy pastorale implementering van 'n eskatologiese model, bicd dit ook vrugbare perspektiewe om die eskatologiese model homileties te ontgin. 'n Kerugmatiese struktuur wat slegs die elemente van die indikatief en die imperatief bevat, is in die lig van Louw se eskatologiese model dus onvolledig. Velema (1976:90) vermeld wel die eskatologiese perspektief van God se komende oordeel as deel van die indikatief, maar dit verlam die dialektiese spanning tussen die alreeds en die nog-nie van die eskatologiese perspektief. Om 'n meer gebalanseerde kerugmatiese struktuur vir die prediking te poneer, sal daar op die voetspoor van Louw ook gepoog moet word om die eskatologiese perspektief in die struktuur te verdiskonteer.

\section{DIE ESKATOLOGIESE MODEL VAN LOUW}

In sy ontwerp van 'n pastorale model kies Louw (1984) vir 'n benadering vanuit 'n eskatologiese perspektief. Die begrip eskatologie kan op verskillende wyses geïnterpreteer word. Hy grens hom in sy denke duidelik af teen 'n moontlike eensydige verstaan van eskatologie, soos byvoorbeeld 'n konsekwente eskatologie, wat uitloop op 'n radikale poging om die ganse geskiedenis van die Christendom aan die uitbly van die paroesie te verbind; 'n futuriese eskatologie waar die heil volledig verskuif word na die eindhistoriese gebeure; die eksistensiële eskatologie wat vra na die uitwerking van die eskatologie op die menslike bestaan (Louw 1984:32-33). Teenoor hierdie eensydige verstaansmoontlikhede, poneer hy dan sy eie interpretasie van die begrip eskatologie as 'n begrip wat te doen het met die 
heilshistoriese en teleologies-toekomstige element van God se rykshandelinge. Die eskatclogie besit in Christus 'n perfektiese moment en in die Heilige Gees 'n presentiese en eksistensiële moment, terwyl dit in die heilshandeling van God in die geskiedenis ingaan en horisontaal verwys na 'n futuriese moment aan die einde van die geskiedenis (Louw 1984:33).

Samevattend kan gesê word dat die eskatologie 'n drieledige struktuur besit.

- Dit is gerealiseerde eskatologie. Die representatiewe dimensie van Christus se heilswerk is die perfektum van die eskaton. Eskatologie is 'n Christologiese, representatiewe eskatologie.

- Dit is presentatiewe eskatologie. Op grond van die inwonende werk van die Heilige Gees verkeer die eskatologie in 'n proses van realisering. Eskatologie is 'n pneumatologiese, inkorporatiewe eskatologie.

- Dit is futuriese eskatologie. Binne die belofte-in-vervulling-struktuur van die heil is die eskatologie teologies gerig op die voleinding (Louw 1984:36).

In die verdere uitwerk van sy model word dit duidelik dat hy die dialektiese spanning tussen die alreeds en die nog-nie verdiskonteer (Louw, in Smuts 1989:25). Die bestaan van die nuwe mens is onderworpe aan 'n voortdurende spanning. Hierdie spanning is tweërlei van aard. Dit is 'n spanning wat deur die eskatologiese voorbehoud opgeroep word, naamlik die spanning tussen die alreeds en die nog-nie. Aan die een kant deel deel die nuwe mens reeds volledig in die volheid van die heil (alreeds), aan die ander kant leef hy in die hoop en is hierdie volheid in hierdie bedeling nog nie volledig aan hom gerealiseer nie (nog-nie) (Louw 1993:146). Die neweproduk van hierdie eskatologiese model is die Christelike hoop. Die hoop geld dan nie hier as plaasvervanger vir die leemtes in die menslike bestaan nie. Die hoop ontspring nie aan 'n eksistensiële gebrek nie, maar aan die beloftes op teologiese vlak, vanuit die trou van God en sy beloftes (Louw 1984:37). In pastorale terme praat hy daarom ook van 'n promissioterapie, waar die mens leef vanuit die trou en die beloftes van God. Dit skep hoop en lei tot 'n nuwe intensie en doelgerigtheid; die hoop transendeer, relativeer en transformeer die gebreke en lyding in hierdie bedeling; die hoop aktiveer en motiveer om te volhard in ' $n$ lewe van geloof (Louw 1984:59-60).

Louw se eskatologiese model aksentueer ook die spanning tussen die indikatief en die imperatief van die heil. Dit beteken dat die nuwe lewe aan die een kant verkondig word as vrug van die heilswerk van God in Christus deur die Heilige Gees (die indikatief van die heil wat verwys na die objektiewe dimensie daarvan). Aan die ander kant word die heil verkondig as 'n kategoriese eis waarop die mens met verantwoordelikheid moet reageer (die imperatief van die heil wat verwys na die 
subjektiewe en sosiale implikasies van die heil). Die spanning indikatief en imperatief beteken dat terwyl die mens aan die oorsprong van die heil geen aandeel het nie, hy, wat die toepassing van die heil betref, ' $n$ verantwoordelikheid besit. Die imperatief is in die indikatief gefundeer (Louw 1993:146).

Met die ontwerp van hierdie eskatologiese perspektief op sy pastorale model, wil Louw hom afgrens teen 'n eduktiewe benadering in die pastoraat, waar die menslike potensiaal die deurslaggewende word. Andersyds waarsku hy teen die eensydigheid van die kerugmatiese model wat die antropologie bloot laat opgaan in die soteriologie. Teologies gesien, is daar by hom 'n gesonde balans tussen die verkondiging van die objektiewe heil, waarin die verlossing, regverdiging en heiligmaking van die mens in Christus en deur die werking van die Heilige Gees, 'n werklikheid geword het, maar vanuit hierdie nuwe werklikheid word die mens opgeroep om te volhard in 'n lewe van geloof en gehoorsaamheid tot eer van God. Die beloftes van God bring die hoop om te volhard, selfs te midde van 'n gebroke werklikheid.

\section{DIE KERUGMATIESE STRUKTUUR}

Hierdie eskatologiese model kan ook met groot vrug in die prediking toegepas word. Hieruit blyk dit duidelik dat die basiese struktuur van die Bybelse kerugma altyd afspeel in die spanningsveld van indikatief, imperatief en beloftes.

\subsection{Die indikatief van die kerugma}

Soos reeds aangetoon, funksioneer die indikatief binne die kerugmatiese struktuur as die begronding van die intensie van die kerugma. Die heilsdade van God in die geskiedenis moet voortdurend weer oorvertel, geproklameer, verkondig word. Bohren (1980:159-167) onderstreeep die belangrikheid van die oorvertel of die 'Erinnerung' van die dade van God in die verlede as die begronding van die prediking. Die perfektiese moment van Louw se eskatologiese model vorm ook die basis of die begronding vir die lewe van die gelowige. Hierdie heilswerk van God is vas en seker, dit word aan die gelowige deur die werking van die Heilige Gees as sy eiendom geskenk (vergelyk die Doopformulier). In feitlik elke perikoop in die Bybel word daar sekere indikatiewe uitgespel wat dan as begronding van die imperatiewe geld. In sommige perikope word daar nie indikatiewe gegee nie, maar vanuit die makro-konteks word dit gou duidelik dat die imperatiewe van die bepaalde perikoop teruggryp na voorafgaande indikatiewe wat reeds geproklameer is. Die imperatiewe van die paranetiese gedeeltes van Efesiërs 5 en 6, is begrond in die indikatief van die nuwe lewe in Christus wat reeds in hoofstuk 1-4 beredeneer is. Die indikatiewe van die bepaalde, of voorafgaande gedeeltes, of van die Skrif- 
boodskap as geheel (Greidanus 1988:169), moet in die prediking teologies geïnterpreteer en vir die gemeente van vandag vertolk word. Slegs op grond daarvan, kan die gemeente opgeroep word om die imperatiewe van die kerugma te verwesenlik. Dan is die verkondiging van die imperatief nie moralisme nie, maar die logiese gevolg van die nuwe lewe in Christus waaraan die gelowige uit genade deel gekry het.

\subsection{Die beloftes van die kerugma}

In die eskatologiese model van Louw, funksioneer die beloftes van God as die motivering en aktivering om te volhard in 'n lewe van geloof. 'n Lewe van hoop, gegrond in die beloftes van God, gee aan die gelowige die krag om die gebrokenheid, onvolledigheid en selfs die lyding te transendeeer en te transformeer. Hierdie hoop skep 'n nuwe intensie en doelgerigtheid. Pieterse (1988:20) beklemtoon ook die belangrikheid van die kategorie van die belofte in die prediking van die Woord van God. Moltmann (1969:32) stel dat die Reformatore in die kategorie van die belofte die korrelasie tussen die praesentia Christi vir die geloof en die gepredikte Skrifwoord gesien het. Die mens word tot geloof opgeroep en in die geloof versterk op grond van die beloftekarakter van die Skrif. Die evangelie as belofte is op konkrete lewende mense gerig (Firet 1977:53). Pieterse (1988:20), haal Noordmans (1934:14) aan wat sê dat die prediker met 'n sak vol beloftes op die preekstoel moet klim. Louw (1984) stel dat die oorwinningsmotief versterk word deur die feit dat die hoop gedra word deur die vervullende aspek van die beloftes. Dit is God self wat sy beloftes vervul en sodoende verhoed dat die eskatologiese heilsboodskap uit die horison van die skepping en die geskiedenis verdamp tot 'n utopiese hersenskim.

Dit is ook van belang om hier vanuit die insigte van die leerteorieë die aandag te vestig op die internalisering van kennis wat lei tot verandering. Motivering tot verandering word deels ook aangewakker deur ekstrinsieke faktore soos straf en beloning (Dingemans 1986:107-108). In die opvoedingsproses van die kind speel positiewe (beloning) en negatiewe (straf) prikkels tot vandag toe nog 'n belangrike rol in gedragsverandering. Alhoewel die beloftes van die evangelie nie meteen aan hierdie prikkels tot gedragsverandering gelykgestel kan word nie, is daar tog, merkwaardig genoeg, telkens in die Bybelse boodskap die beloftes van God se straf en oordeeel (negatief), asook die beloftes van God se seën en sy troue sorg (positief). Die beloftes van God se seën kan nie gesien word as beloning op goeie werke nie, maar as die versekering en toesegging van God se genade wat reeds in en deur die verdienste van Christus, 'n heilswerklikheid vir die gelowige is. Die voortdurende herhaling van hierdie beloftes (positief en negatief) is die motivering 


\section{Kcrugmaticse struktuur}

om in die geloof te volhard en in geloofsgehoorsaamheid voor God te lewe. Hierdie insig vanuit die leerteorieë onderstreep die belangrikheid van die beloftes van God in die samehang van die kerugmatiese struktuur.

'n Verdere perspektief vanuit die leerteorieè wat aandag verdien, is die beklemtoning van die feit dat die doelwitte van die leerproses gerig moet wees op drie vlakke (Dingemans 1986:206), naamlik: die kognitiewe vlak (die verwerwing van eksakte kennis); die affektiewe vlak (oordeels- en gesindheidsvorming); die attidunale (vaardigheidsvlak wat uitmond in ' $n$ bepaalde lewenshouding en handeling). Die elemente van die kerugmatiese struktuur vertoon ooglopende ooreenkomste met die drie genoemde doelwitte van die leerproses. In 'n sekere sin kan die doel van die indikatief in verband gebring word met die kognitiewe. Die gelowige moet die kennis besit van die heilshandelinge van God in die verlede. Hierdie kennis moet deurlopend in die prediking deur die proklamering van die heilsindikatief, ingeskerp word. Die beloftes in die kerugmatiese struktuur opereer op die vlak van die affektiewe. Die beloftes van God (positief en negatief) kweek by die mens 'n bepaalde gesindheid van hoop en volharding. Die imperatiewe vertoon weer op sy beurt ooreenkoms met die attidunale. Dit bring die mens in beweging, dit lei tot verandering in lewenshouding en gedrag. Pieterse (1988:33) wys op die belangrikheid om, veral in leerprediking, die hoorder op aldrie die vlakke te begelei. Die internalisering van die leerinhoude wat op genoemde drie vlakke plaasvind, aksentueer die belangrikheid en interafhanklikheid van die onderskeie elemente binne die struktuur van die kerugma.

Wanneer die prediker die sensitiwiteit ontwikkel om in die eksegese van die perikoop doelbewus te let op die beloftes, kom 'n mens tot die verstommende ontdekking dat feitlik elke perikoop, eksplisiet of implisiet, op die beloftes van God wys. Wanneer die beloftes nie in die mikro-konteks na vore kom nie, is dit wel aanwesig in die breër makro-konteks. In die prediking kan die beloftes nie los van die samehang van die kerugmatiese struktuur oorgebring word na vandag toe nie. Die beloftes sal binne die verband van die boodskap teologies vertolk moet word in 'n nuwe konteks. Dit bly 'n moeilike en gewaagde onderneming, maar dit mag nie daartoe lei dat die prediker die beloftes in die kerugma negeer nie, want dan word die inherente dinamiek van die hoodskap geskaad.

\subsection{Die imperatief en intensie van die kerugma}

Hermeneuties gesien, sou 'n mens dit ook so kon formuleer dat die verkondiging van die indikatief en die beloftes van God, die gelowige in beweging wil bring om die intensie (of imperatief) van die boodskap na te jaag. Verkondiging van die Woord het nie bloot ten doel om aan die gemeente oor te dra wat in 'n eeu-oue teks 
geskryf staan nie, maar juis om deur die hermeneutiese proses en verplasing van dinamiese inhoude die intensie van die teks in die hede ter sprake te laat kom (Pieterse 1979:118). Pieterse baseer sy standpunt op die siening van Ebeling (1975:342) dat prediking in sy wese 'n Woordgebeure is. Deur die Woordgebeure word die prediker gekonfronteer in al die kontoere van sy bestaan, hy word deur die teks geïnterpreteer en sy bestaan word deur die teks uitgele. So kom die prediker tot verstaan en tot 'n nuwe selfverstaan. Hierdie intensie van die boodskap moet aan die gemeente in hulle situasie invertaal word sodat hulle ook tot 'n nuwe selfverstaan sal kom (Pieterse 1979:119). Dingemans (1991:175) beklemtoon ook die belangrikheid dat die inherente dinamiek van Bybelse tekste mense in beweging wil bring, hulle moet die appel van die kerugma hoor! Hierdie intensie, of bedoeling van die teks, sou ons vir die doel van die kerugmatiese struktuur van die prediking, die imperatief wil noem. Soms word die imperatief van die perikoop eksplisiet uitgespel, maar in ander gevalle lê dit verskuil in die dinamiek van die boodskap. Wanneer die imperatiewe of die intensie van die kerugma nie eksplisiet verwoord word nie, moet die prediker in die meditasie (Pieterse 1979:113-117) en eksegetiese proses, die indikatiewe en beloftes van die perikoop op hom laat inwerk totdat hy die verskuilde imperatief of intensie gesnap het. Die bedoeling van die prediking is nie slegs die applicatio van die teks se boodskap nie, maar dat die saak van die teks self tot volle gelding in die hede moet kom. Greidanus (1988:104 w) wys ook op die belangrikheid dat die bedoeling of intensie van die outeur gesnap moet word binne die verband van die perikoop en die Skrif. Afsonderlike elemente van die kerugma, soos die imperatiewe, kan nie net so oorgedra word nie, maar kan slegs reg verstaan word binne die onderlinge samehang van die boodskap as geheel (Greidanus 1988:163-169). Die identifisering van die indikatiewe en beloftes van die kerugmatiese struktuur binne die bepaalde perikoop, is vir die homileet 'n hulpmiddel om die intensie of imperatief te snap. Die handhawing van die kerugmatiese struktuur in die vertolking daarvan na die gemeentelike situasie, bevry die prediker van blote moralisme.

\section{HOMILETIESE IMPLEMENIERING}

Om die onderskeie elemente van die kerugmatiese struktuur in hulle onderlinge samehang vir die prediking te ontgin, moet daar gepoog word om 'n homiletiese werkwyse te poneer wat hieraan reg sal laat geskied. Nadat die homileet die moeisame eksegetiese weg bewandel het om die teks vanuit verskillende eksegetiese lense te ondersoek, moet hy by die punt kom waar hy die eksegetiese skopus van die perikoop kort en bondig kan formuleer (Pieterse 1979:101-112). Die eksegetiese proses lei die homileet tot die kern van dit wat daar in die perikoop staan 
(eksegetiese skopus). Die prediker vra egter dieper en verder na die betekenis, die intensie van die perikoop. Hy wil by die punt kom waar hy kan ontdek wat die kerugma van die bepaalde perikoop in die gemeente van vandag wil laat gebeur (Dreyer 1989). Dit vind plaas deur die verstaansontmoeting en vertaling deur die Woordgebeure in die meditasie (Pieterse 1979:113-117). As deel van hierdie proses kan die identifisering van die onderskeie elemente van die kerugmatiese struktuur vir die prediker tot groot hulp wees. Soos reeds aangetoon, lei die homiletiesteologiese deurdenking van die kerugmatiese struktuur die homileet dikwels tot die ontdekking van die intensie van die kerugma. Ter illustrasie word enkele praktiese voorbeelde van so 'n homiletiese werkwyse aangebied.

\subsection{Hebreërs 10:19-25}

Die eksegetiese proses lei tot die vasstelling van die volgende eksegetiese skopus: Jesus Christus het deur sy bloed die weg tot God gebaan. In kort kan die kerugmatiese struktuur van die perikoop soos volg weergegee word:

\begin{tabular}{l}
\begin{tabular}{|l|l|l|}
\hline Indikatiewe & Imperatiewe & Beloftes \\
\hline $\begin{array}{l}\text { Jesus is hoëpries- } \\
\text { ter }\end{array}$ & Ons moet: & God is getrou \\
- baan weg deur & $-\begin{array}{l}\text { vashou aan die } \\
\text { voorhangsel } \\
\text { hoop }\end{array}$ & - hou sy beloftes \\
harte is gerei- & $-\begin{array}{l}\text { sien om na me- } \\
\text { naar }\end{array}$ & $-\begin{array}{l}\text { oordeelsdag kom } \\
\text { nader }\end{array}$ \\
- deur Jesus vrye \\
toegang tot God \\
onderlinge by- \\
eenkoms nie ver- \\
waarloos
\end{tabular} \\
\hline
\end{tabular}

Die eksegetiese skopus van hierdie gedeelte ontbloot die grondargument waarop alles berus, naamlik dat Jesus Christus as die Hoëpriester deur sy offer eens-en-viraltyd die weg deur die voorhangsel heen tot God gebaan het. As slegs hierdie grondliggende indikatief verkondig word, sal dit die gemeente lei tot 'n beter kennis en verstaan van die heilsdaad van God in Jesus Christus. Hierdie kerngedagte wat geproklameer word, het egter 'n bepaalde intensie of bedoeling. Die gelowige moet op grond van hierdie indikatief aangespoor word om die imperatief na te streef as noodwendige konsekwensie van die indikatief. Die bedoeling van hierdie boodskap is om die gemeente tot die oortuiging te bring dat hulle kan vashou aan die hoop, omdat dit gegrond is in die versoening met God deur Jesus Christus. Hierdie vashou aan die hoop sal na vore kom in die aanvaarding van die verantwoordelik- 
heid om na mekaar om te sien en aan te spoor tot liefde en goeie dade en om nie die onderlinge byeenkomste te verwaarloos nie. Die imperatief, om vas te hou aan die hoop, word gemotiveer deur die belofte dat God getrou is en sy belofte hou. Die gemeente word ook angespoor tot volharding met die belofte dat die oordeelsdag nader kom en die dreiging wat dit inhou as daar nie aan die hoop vasgehou word nie. Homileties is die intensie van die kerugma in hierdie perikoop om die gelowige daartoe te beweeg om vas te hou aan die hoop. Indien die prediker met verbygaan van die indikatiewe die gemeente sou oproep tot die verantwoordelikheid om na mekaar om te sien en die vermaning om nie die onderlinge byeenkomste te verwaarloos nie, sou dit neerkom op blote moralisme. Geanker in die indikatiewe en gedra deur die beloftes van God is hierdie imperatiewe van alle moralisme ontdaan en is dit die oproep tot die nuwe bestaanswyse wat deur die geloof in Jesus Christus 'n werklikheid geword het.

\subsection{Psalm 29}

Die eksegese van Psalm 29 wys daarop dat die skopus van die Psalm neerkom op die feit dat God mag het en oor alles regeer. Die kerugmatiese struktuur sien soos volg daaruit:

\begin{tabular}{|l|l|l|}
\hline Indikatiewe & Imperatiewe & Beloftes \\
\hline God is almagtig & Let wel: Geen eks- & God gee sy volk \\
- grootste in die & plisiete impera- & krag \\
- hemel en op & tief aanwesig. & - seen hulle \\
aarde & Verskuilde impera- & - Hy is vir ewig \\
Hy heers oor: & tief: & Moenie bang wees! \\
- natuurkragte & koning \\
- berge en plante & Vertrou op God & \\
- diere en woestyn & & \\
\hline
\end{tabular}

Begronding

Aansporing

Die eksegese het as skopus aangedui dat God mag het en oor alles regeer. Dit is die indikatief wat geproklameer was binne die verstaanshorison van die implisiete hoorders. Binne hulle konteks word die indikatief van God se almag duidelik by wyse van sy beheer oor die natuurkragte en selfs die chaosmagte. Hierdie indikatief word gedra deur die belofte van die seën en krag wat Hy hulle skenk, asook die sekerheid dat Hy vir ewig Koning is. Geen duidelike imperatief kom na vore nie. Die konteks van die implisiete hoorder of leser van die teks, is 'n mitologiese wêreld wat gekenmerk word deur die vrees vir die natuurkragte. Omringende volke het 
deur hulle afgodsdiens gepoog om hierdie natuurkragte gunstig te stem. Wanneer die homileet hom meditatief in hierdie konteks inleef, kom hy tot die ontdekking dat die indikatiewe en die beloftes van die Psalm juis die hoorder daartoe wil bring om nie hierdie magte te vrees nie, maar om op die almagtige God te vertrou, omdat Hy oor alles mag het en regeer. Binne die samehang van die kerugmatiese struktuur word die intensie van die perikoop duidelik. Homileties gesien, lê die skopus van die prediking daarin opgesluit dat die verkondiging van God se almag en regering die gelowige daartoe wil bring om nie die omringende magte van die wêreld te vrees nie, maar op God te vertrou.

\section{GEVOLGTREKKINGS}

As hipotese vir hierdie ondersoek is gestel dat die handhawing van die kerugmatiese struktuur as bolwerk teen moralisme in die prediking kan dien. Die ondersoek het aangetoon dat indien die imperatiewe binne die samehang van die kerugmatiese struktuur verkondig word, dit wel die prediking van moralisme kan bevry. Die kerugmatiese struktuur dwing die prediker om te vra na die indikatiewe en beloftes wat gegrond is in die heil en trou van God. Die moontlikheid dat afsonderlike elemente van die teks in isolasie na vandag oorgedra kan word, word ook hierdeur ondervang. Die kerugmatiese struktuur bevry ook die prediking van teologiese armoede, omdat dit die prediker ncop om die indikatiewe en beloftes in die breër teologiese raamwerk van die Skrifboodskap te interpreteer. Verder hou die kerugmatiese struktuur die voordeel in dat dit al drie vlakke van die menslike leerproses tot hulle reg laat kom. Dit vrywaar op sy beurt die prediking enersyds van 'n eensydige kognitiewe aanslag, maar andersyds versper dit ook die weg na 'n oordrewe en kunsmatige emosionaliteit in die prediking.

Binne die samehang en wisselwerking van die afsonderlike elemente van die kerugma, kan die dinamiek van die Woordgebeure gelowiges in beweging bring en laat volhard op pad na die voleinding.

\section{Literatuurverwysings}

Bohren, R 1980. Predigtlehre. München: Kaiser Verlag.

Bornkamm, G 1961. s v Paulus. Religion in Geschichte und Gegenwan, Band V.

De Reuver, A 1986. Iets over de verlossing en de wet bij Calvijn: Een leesoefening in De Institutie. ThRef 29, 50-62.

Cox, J W 1985. Preaching. San Francisco: Harper \& Row.

Dingemans, G D J 1986. In de leerschool van het geloof. Kampen: Kok. 
Dingemans, G D J 1991. Als hoorder onder de hoorders...Een hermeneutische homiletiek. Kampen: Kok.

Dreyer, T F J 1989. 'n Poging tot 'n herdefinisie van die prediking binne die raamwerk van die Reformatoriese Teologie. HTS 45, 350-369.

Ebeling, G 1975. Wort und Glaube, Dritter Band. Tübingen: Mohr.

Fitzgerald, C S P 1980. A practical guide to preaching. New York: Paulist Press.

Floor, L 1974. Die indikatief en die imperatief in die prediking. ThRef 17, 19-33.

Fuchs, O 1992. Towards an indicative preaching. Praktiese Teologie in Suid-Afrika 7, 113-118.

Firet, J 1977. Het agogisch moment in het pastoraal optreden. Kampen: Kok.

Greidanus, S 1988. The modern preacher and the ancient text. Leicester: InterVarsity Press.

Jonker, $\mathrm{H}$ et al s a. Actuele prediking. Nijkerk: Callenbach.

Kotze, G J 1963. Hedendaagse Skrifprediking: 'n Ondersoek na die mistastinge in die prediking van die nuwere tyd. Potchefstroom: Pro Rege.

Louw, D J 1984. Pastoraat in eskatologiese perspektief. Pretoria: N G KerkUitgewers.

- 1984. Teologie in hoop. Kaapstad: N G Kerk-Uitgewers.

- 1993. Pastoraat as ontmoeting. Pretoria: RGN.

Moltmann, J 1969. Theologie van de hoop. Utrecht: Ambo.

Noordmans, O 1934. Herschepping. Zeist: Nederlansche Christen-StudentenVereniging.

Pieterse, H J C 1979. Skrifverstaan en prediking. Pretoria: NGKB.

- 1988. Die woord in die werklikheid. Pretoria: NGKB.

Smuts, A J (red) 1989. Pastoraat en pastorale praktyk. Pretoria: Academica.

Trilhaas, W. s v Moralismus. Religion in Geschichte und Gegenwart, Band IV.

Trimp, C 1984. Heilshistorische Prediking. NGTT 25, 188-195.

Van Rensburg, J J \& Kellerman, J S 1992. 'n Kritiese ontleding van moralisme in die prediking. NGTT 33, 216-224.

Velema, W H 1987. Ethiek en pelgrimage: Over de bijbelse vreemdelingskap. Amsterdam: Ton Bolland.

Wiederkehr, D 1982. Predigt und Eucharistiefeier: Komplementêre Gestaltes Kirchlicher Verkündigung, in Schuepp, G et al, Handbuch zur Predigt, 159-184. Zurich: Benziger. 